\title{
O070: Abstract withdrawn
}

From 2nd International Conference on Prevention and Infection Control (ICPIC 2013)

Geneva, Switzerland. 25-28 June 2013

Published: 20 June 2013

doi:10.1186/2047-2994-2-S1-070

Cite this article as: : O070: Abstract withdrawn. Antimicrobial Resistance and Infection Control 2013 2(Suppl 1):070.

Submit your next manuscript to BioMed Central and take full advantage of:

- Convenient online submission

- Thorough peer review

- No space constraints or color figure charges

- Immediate publication on acceptance

- Inclusion in PubMed, CAS, Scopus and Google Scholar

- Research which is freely available for redistribution

Submit your manuscript at www.biomedcentral.com/submit 